\title{
Optogenetic Activation of Colon Epithelium of the Mouse Produces High-Frequency Bursting in Extrinsic Colon Afferents and Engages Visceromotor Responses
}

\author{
Payal A. Makadia, ${ }^{1 *}{ }^{\oplus S}$ Sarah A. Najjar, ${ }^{2 *} \oplus$ Jami L. Saloman, ${ }^{2}$ Peter Adelman, ${ }^{2}{ }^{\oplus}$ Bin Feng, ${ }^{2}{ }^{-}$Joseph F. Margiotta, ${ }^{3}$ \\ ㅈathryn M. Albers, ${ }^{2}$ and $\odot$ Brian M. Davis ${ }^{2}$ \\ ${ }^{1}$ Department of Pediatrics, Children's Hospital of Pittsburgh, University of Pittsburgh Medical Center, Pittsburgh, Pennsylvania 15224, ${ }^{2}$ Department of \\ Neurobiology, University of Pittsburgh School of Medicine, Center for Pain Research, Center for Neuroscience at the University of Pittsburgh, Pittsburgh, \\ Pennsylvania 15261, and ${ }^{3}$ Department of Neurosciences, University of Toledo, Toledo, Ohio 43614
}

Epithelial cells of the colon provide a vital interface between the internal environment (lumen of the colon) and colon parenchyma. To examine epithelial-neuronal signaling at this interface, we analyzed mice in which channelrhodopsin (ChR2) was targeted to either TRPV1-positive afferents or to villin-expressing colon epithelial cells. Expression of a ChR2-EYFP fusion protein was directed to either primary sensory neurons or to colon epithelial cells by crossing Ai32 mice with TRPV1-Cre or villin-Cre mice, respectively. An ex vivo preparation of the colon was used for single-fiber analysis of colon sensory afferents of the pelvic nerve. Afferents were characterized using previously described criteria as mucosal, muscular, muscular-mucosal, or serosal and then tested for blue light-induced activation. Light activation of colon epithelial cells produced robust firing of action potentials, similar to that elicited by physiologic stimulation (e.g., circumferential stretch), in 50.5\% of colon afferents of mice homozygous for ChR2 expression. Light-induced activity could be reduced or abolished in most fibers using a cocktail of purinergic receptor blockers suggesting ATP release by the epithelium contributed to generation of sensory neuron action potentials. Using electromyographic recording of visceromotor responses we found that light stimulation of the colon epithelium evoked behavioral responses in Vil-ChR2 mice that was similar to that seen with balloon distension of the colon. These ex vivo and in vivo data indicate that light stimulation of colon epithelial cells alone, without added mechanical or chemical stimuli, can directly activate colon afferents and elicit behavioral responses.

Key words: channelrhodopsin; nociceptor; pain; visceral

Significance Statement

Abdominal pain that accompanies inflammatory diseases of the bowel is particularly vexing because it can occur without obvious changes in the structure or inflammatory condition of the colon. Pain reflects abnormal sensory neuron activity that may be controlled in part by release of substances from lining epithelial cells. In support of this mechanism we determined that blue-light stimulation of channelrhodopsin-expressing colon epithelial cells could evoke action potential firing in sensory neurons and produce changes in measures of behavioral sensitivity. Thus, activity of colon epithelial cells alone, without added mechanical or chemical stimuli, is sufficient to activate pain-sensing neurons.

\section{Introduction}

The epithelial-lined mucosa of the colon is innervated by autonomic and sensory nerve fibers of intrinsic and extrinsic origin

Received March 30, 2018; revised May 14, 2018; accepted May 16, 2018.

Author contributions: P.A.M. wrote the first draft of the paper; P.A.M., S.A.N., K.M.A., and B.M.D. edited the paper; P.A.M., S.A.N., K.M.A., and B.M.D. designed research; P.A.M., S.A.N., J.L.S., P.A., B.F., J.F.M., K.M.A., and B.M.D. performed research; P.A.M., S.A.N., P.A., J.F.M., K.M.A., and B.M.D. analyzed data; K.M.A. and B.M.D. wrote the paper.

This work was supported by funding provided by the National Institutes of Health: T32 DK063922 (P.A.M.) and T32 NS07433 (S.A.N.), T32 NS086749/T32 NS073548 (J.L.S.), AR066371 (K.M.A.), R01AR066951 (K.M.A., B.M.D.), and OT20D023859 (Marthe Howard, University of Toledo, Pl; subcontract to B.M.D., K.M.A.). We thank Dr. Jane
(Spencer et al., 2014). Understanding how activation of these nerve fibers is regulated at this important interface is of significant

Hartung for help with figure design, Michael Chiang for help in fiber optic assembly, and Christopher Sullivan for technical support.

The authors declare no competing financial interests.

*P.A.M. and S.A.N. contributed equally as co-first authors.

Correspondence should be addressed to either Dr. Brian M. Davis or Dr. Kathryn M. Albers, University of Pittsburgh, Department of Neurobiology, BSTWR, 200 Lothrop Street, Pittsburgh, PA 15261, E-mail: bmd1@pitt.edu or ka22@pitt.edu.

B. Feng's present address: University of Connecticut, Department of Biomedical Engineering, Storrs, Connecticut 06269.

DOI:10.1523/JNEUROSCI.0837-18.2018

Copyright $\odot 2018$ the authors $\quad 0270-6474 / 18 / 385788-11 \$ 15.00 / 0$ 
clinical and biological interest, particularly for understanding their role in pain signaling in chronic inflammatory conditions of the gut. In recent studies of the epithelium covering the skin it has been possible to demonstrate that excitation of epithelial cells alone can directly produce action potentials in primary sensory neurons in the absence of naturalistic mechanical, thermal, or chemical stimulation (Maksimovic et al., 2014; Baumbauer et al., 2015; Pang et al., 2015). Epithelial cells, genetically modified to express channelrhodopsin (ChR2) and stimulated with blue light, were shown to elicit firing in diverse types of cutaneous sensory neurons, including those that sense pain and mechanical stimuli (Baumbauer et al., 2015).

The colon epithelium, comprised of absorptive enterocytes, endocrine cells, and goblet cells has features in common to the skin epithelium; it interfaces with the internal environment of the gut and is the first line of defense for the colon, protecting it from a wide range of pathogenic and chemical insults within the colon lumen. Similar to keratinocytes of the skin, colon epithelial cells can release several types of neuro-activator compounds, including classic neurotransmitters such as acetylcholine (ACh), ATP, and 5-hydroxytrypamine (5-HT/serotonin), and peptides and hormone transmitters, such as somatostatin and peptide YY (Rindi et al., 2004; Bertrand, 2009; Gunawardene et al., 2011). Released neuromodulators are thought to both stimulate and inhibit neurons of the myenteric plexus, as well as act on primary sensory afferents from the dorsal root ganglia (DRG), through activation of metabotropic and ionotropic receptor proteins, e.g., muscarinic or nicotinic acetylcholine receptors, purinergic receptors, and/or serotonergic receptors (Bertrand, 2003; Linden et al., 2003; Wynn et al., 2004; Bornstein, 2006; Burnstock, 2014; King, 2015; Liñán-Rico et al., 2015; Mawe, 2015).

Few studies have examined how compounds, potentially derived from the colon epithelium, can initiate neuronal action potentials in the absence of other naturalistic stimuli (Wynn et al., 2004; Hockley et al., 2016; Bellono et al., 2017). Given the inconclusive evidence for direct activation of nerve fibers by colon epithelial cells and the recent finding that skin epithelial cells can independently initiate action potentials in DRG sensory fibers, we examined the contribution of the colonic epithelium to generation of action potentials in colon sensory afferents. To allow epithelial-specific activation we targeted ChR2 to colonic epithelial cells to determine whether light-induced activation of these cells could generate action potentials in extrinsic sensory afferents. Our results show that almost one-half of all colon afferents fired high-frequency trains of action potentials in response to light activation of the epithelium, often in patterns similar to those evoked by mechanical stimulation. In addition, the response of $70 \%$ of the epithelial-activated afferents exhibited a significant decrease in firing frequency when stimulated in the presence of blockers of P2X-and P2Y-receptor-mediated neurotransmission, suggesting that ATP and/or UTP are major components of epithelial cellcolon afferent excitation coupling. Using the visceromotor response (VMR) as an in vivo assay, it was also determined that light stimulation of epithelial lining cells alone is sufficient to elicit behavioral changes similar to those obtained in response to colon distension. That colon epithelial cells alone have the ability to directly initiate afferent firing and cause behavioral response supports a central role for these cells in colon function and physiology and indicate that the epithelium not only serves as a barrier and source of chemical modulators, but also provides a means for direct transmission of stimuli from the colon lumen to the nervous system.

\section{Materials and Methods}

Animals. Male and female mice 6-10 weeks of age were analyzed. Mice with a fusion protein of ChR2 and EYFP [ChR2(H134R)-EYFP] in the Rosa26 locus downstream of a floxed-STOP cassette (Ai32 mice; RRID: IMSR_JAX:012569) were crossed with either TRPV1 ${ }^{\text {Cre }}$ (RRID:IMSR_JAX: 017769) or villin ${ }^{\text {Cre }}$ mice (RRID:IMSR_JAX004586). Littermates with ChR2-EYFP but lacking Cre were used as controls. Animals were maintained in an association for assessment and accreditation of laboratory animal care (AAALAC) approved facility and handled following protocols approved by the University of Pittsburgh Institutional Animal Care and Use Committee.

Tissue immunolabeling. L5, L6, and S1 DRG and distal colon segments were fixed in $4 \%$ paraformaldehyde, cryoprotected in $25 \%$ sucrose, embedded in optimal cutting temperature (OCT) compound and sectioned on a cryostat at either $14 \mu \mathrm{m}$ (for DRG) or $20 \mu \mathrm{m}$ (for colon). Air dried sections were washed in phosphate buffered saline (PBS), incubated overnight at room temperature in anti-PGP 9.5 (1:500; rabbit polyclonal, ThermoFisher, PA1-21097; RRID:AB_560757) made in PBS/0.25\% Triton X-100, washed, incubated in donkey anti-rabbit-Cy3 (1:500; Jackson ImmunoResearch), washed, coverslipped, and images captured using a digital camera attached to a Leica DM4000B microscope.

Reverse-transcriptase polymerase chain reaction analysis. The relative expression level of ChR2-YFP mRNA was determined using reverse transcriptase PCR analysis. Total RNA isolated from the distal colon was purified using the Quick-RNA miniprep kit (Zymo Research), DNased (Invitrogen), and reverse-transcribed using Superscript II (Invitrogen). Primers for ChR2 (5'TGG CTC TGT ACT TGT GCC TG3' and 5'TGA CCA TCT CGA TAG CGC AC3') and GAPDH (5'ATG TGT CCG TCG TCG TGG ATC TGA and 5'ATG CCT GCT TCA CCA CCT TCT T3') were used in SYBR Green PCR amplification reactions performed using a Bio-Rad CFX system. Relative fold-change was calculated using the $\Delta \Delta C_{t}$ method with GAPDH as standard.

In vitro single-fiber recording from colon-pelvic nerve. Mice killed with isoflurane were transcardially perfused with carbogenated $\left(95 \% \mathrm{O}_{2}, 5 \%\right.$ $\mathrm{CO}_{2}$ ) ice-cold artificial CSF (ACSF) containing the following (in mM: 117.9 NaCl, $4.7 \mathrm{KCl}, 25 \mathrm{NaHCO}_{3}, 1.3 \mathrm{NaH}_{2} \mathrm{PO}_{4}, 1.2 \mathrm{MgSO}_{4}-7 \mathrm{H}_{2} \mathrm{O}, 2.5$ $\mathrm{CaCl}_{2}, 11.1 \mathrm{D}$-glucose $)$ and the distal colorectum $(\sim 3 \mathrm{~cm})$ removed with the attached major pelvic ganglion and pelvic nerve $(\mathrm{PN})$. Tissues were transferred to ice-cold modified Krebs' solution (Krebs' solution containing $2 \mathrm{~mm}$ butyrate, $20 \mathrm{~mm}$ sodium acetate, $4 \mu \mathrm{M}$ nifedipine, and $3 \mu \mathrm{M}$ indomethacin bubbled with carbogen (Brierley et al., 2004; Feng et al., 2010) and then to an acrylic organ bath consisting of two adjacent chambers separated by a plastic gate with a small opening. The colon was opened longitudinally along the mesenteric border, placed in a Sylgard 182 (Dow Corning) lined chamber with circulating Krebs' maintained at $34^{\circ} \mathrm{C}$ and pinned flat with mucosal side up. The spinal nerve containing afferents from the L6 DRG, which contributes to both the pelvic nerve and lumbar splanchnic nerve, was dissected and followed out to the fat pad located near the junction of the bladder and the colon (see Fig. 2A,B). For the purpose of recording, the entire L6 ventral ramus that gives off branches that run into the fat pad was placed in the recording chamber and the fat pad and nerves contained within positioned under the Plexiglas divider that separates the recording chamber from the colon. To obtain nerve fascicles that contain afferent fibers that innervate the colon, the $\mathrm{L} 6$ ventral primary ramus (i.e., the $\mathrm{PN}$ ) is placed onto a mirror in the recording chamber containing mineral oil. Under a dissection microscope, the nerve sheath was removed and the nerve trunk teased into fine bundles $(\sim 10 \mu \mathrm{m}$ thick) that were placed onto a platinum-iridium recording electrode for single-fiber electrophysiological recordings.

Characterization of pelvic afferents. Teased fibers of the PN were characterized using the classification system described by Lynn and Blackshaw (1999) and Brierley et al. (2004). Fibers that were activated by circumferential stretch were designated as "muscular", or "muscular/ mucosal" if they also responded to gentle stroking of the mucosa. Fibers that only responded to blunt probing were classified as "serosal", whereas those that only responded to gentle mucosal stroking were designated as "mucosal". Receptive fields were identified by first stroking the mucosal surface with a brush to locate mechanosensitive afferents. Responsive- 
ness to blue-light stimulation was then determined using a $473 \mathrm{~nm}$ wavelength laser (Laserglow Technologies) and power meter readings taken to estimate the average wattage reaching the tissue $(40 \mathrm{~mW}$ at maximum power) over a $200 \mu \mathrm{m}$ spot size (delivered via a $100 \mu \mathrm{m}$ fiber-optic light guide). Mechanical stimuli were then applied to further classify afferents as serosal, muscular, mucosal, or muscular/mucosal: probing with nylon monofilaments (von Frey filaments, 1-1.4 g force), mucosal stroking with calibrated nylon filaments (10 $\mathrm{mg}$ force) and circumferential stretch generated using a servo-controlled force actuator (Feng et al., 2010; Aurora Scientific). Custom-made claws (1 mm interval) were attached along a mesenteric edge of the colorectum to allow for uniform circumferential stretch by slow ramped force $(0-170 \mathrm{mN}$ at $5 \mathrm{mN} / \mathrm{s})$. The circumferential stretch generated corresponds to intraluminal pressures of 0-45 mmHg (Feng et al., 2010).

\section{ATP antagonist pharmacology}

Villin-ChR2 responsive afferents. Once receptive fields of fibers were identified with blunt probing, blue-light laser at a minimal intensity $(\sim 1-2$ $\mathrm{mW}$ ) was placed in the field. Light stimulation was removed for 3-5 min to allow the fiber to equilibrate and then turned on at a maximal intensity of $40 \mathrm{~mW}$ for at least $10 \mathrm{~s}$ (but no longer than $60 \mathrm{~s}$ ) to determine whether each afferent responded to light activation of the epithelium. For lightresponsive fibers, a combination of three antagonists was then added to the bath: pyridoxal phosphate-6-azo(benzene-2,4-disulfonic acid) tetrasodium salt hydrate (PPADS; Sigma-Aldrich); P2X antagonist (and P2 $\mathrm{Y}_{1}$ antagonist at higher concentrations than used here); $2^{\prime}, 3^{\prime}-\mathrm{O}-(2,4,6-$ trinitrophenyl) adenosine $5^{\prime}$-triphosphate tetrasodium salt (TNP-ATP; Sigma-Aldrich); $\mathrm{P} 2 \mathrm{X}_{1}, \mathrm{P} 2 \mathrm{X}_{3}, \mathrm{P} 2 \mathrm{X}_{2 / 3}$ antagonist; and AR-C118925XX (selective $\mathrm{P}_{2} \mathrm{Y}_{2}$ antagonist; Tocris Bioscience) at final concentrations of 100,3 , and $10 \mu \mathrm{M}$, respectively. After $10 \mathrm{~min}$ of drug incubation, the fiber was stimulated with blue light for $10 \mathrm{~s}$. The drug cocktail was then washed out for $10 \mathrm{~min}$ or until $600 \mathrm{ml}$ of fresh ACSF had flowed through the recording chamber ( $\sim 20$ times the chamber volume). The field was again stimulated with blue light and response recorded. Response to drug mixture was defined as $\geq 25 \%$ reduction in average firing rate with drug application and recovery of firing rate by $\geq 25 \%$ (Hicks et al., 2002; Brierley et al., 2005).

Stretch-responsive afferents. Effects of the ATP antagonist mixture on stretch activation of TRPV1-ChR2 colon afferents used the same pharmacological protocol but without laser stimulation. Stretch-sensitive fibers were identified and baseline circumferential stretch obtained followed by $10 \mathrm{~min}$ of exposure to the mixture of ATP receptor antagonists. Drugs were washed out and circumferential stretch repeated and the response recorded. For the ATP experiments, five Vil-ChR2 mice (3 male, 2 female) and three TRPV1-ChR2 mice ( 2 male, 1 female) were used.

Data recording and analysis. Action potentials generated by PN afferents were recorded using a low-noise AC differential amplifier (DAM80; World Precision Instruments) as described previously (Feng et al., 2010; Feng and Gebhart, 2011). Electrical signals were filtered $(0.01-10 \mathrm{kHz})$, amplified $(\times 10,000)$, digitized at $20 \mathrm{kHz}$ using a 1401 interface [Cambridge Electronic Design (CED)], monitored online by an audio monitor (Grass AM10; Astro-med) and stored on a personal computer. Action potentials were analyzed using Spike2 software (CED; RRID:SCR_000903). Action potentials were discriminated as single units based on principle component analysis of individual spike waveform. To avoid errors in discrimination, no more than two discernable active units in any record were studied. The fiber stretch threshold $\left(T_{\text {force }}\right)$ was defined as the force that evoked the first action potential during a stretch stimulus (Feng et al., 2010; Feng and Gebhart, 2011). Latency $\left(T_{\text {time }}\right)$ was the time when the first action potential was fired. Analysis of firing rate (hertz) and instantaneous frequency (IF; average and peak) were done over the first $10 \mathrm{~s}$ from the first action potential.

To ensure that light responses in sensory fibers were not due to lasergenerated heating of the tissue, similarly timed light exposures were done using preparations from littermate control mice. Light stimulation in controls did not produce action potential firing.

Culture of primary colon epithelial cells. Colon epithelial cells were acutely dissociated and cultured from the isolated distal colon. The lon- gitudinal muscle layer was teased apart, stripped off, and the remaining tissue was digested with collagenase P (Sigma-Aldrich; $0.09 \mathrm{mg} / \mathrm{ml}$ dissolved in Eagle's Essential Medium containing 1\% glutamine and 1\% bovine serum albumin) for $20 \mathrm{~min}$ at $37^{\circ} \mathrm{C}$, followed by $0.25 \%$ trypsinethylenediamine acid solution for $10 \mathrm{~min}$ at $37^{\circ} \mathrm{C}$. Tissue was then resuspended in Basal Medium Eagle containing 1\% glutamine and 2\% penicillin/streptomycin and mechanically dissociated with fire-polished Pasteur pipettes. Dissociated cells were plated on $15 \mathrm{~mm}$ glass coverslips and maintained at $37^{\circ} \mathrm{C}$ in $5 \% \mathrm{CO}_{2}$. Patch-clamp recordings were performed after $2 \mathrm{~h}$ of incubation.

Whole-cell patch-clamp electrophysiology. Patch-clamp recordings were obtained from ChR2-expressing colon epithelial cells exposed to blue light. Coverslips with plated epithelial cells were transferred to a recording chamber bath maintained at $22^{\circ} \mathrm{C}$ in a solution containing the following (in mм): $117.9 \mathrm{NaCl}, 4.7 \mathrm{KCl}, 25 \mathrm{NaHCO}_{3}, 1.3 \mathrm{NaH}_{2} \mathrm{PO}_{4}, 1.2 \mathrm{MgSO}_{4}, 2.5$ $\mathrm{CaCl}_{2}, 11.1 \mathrm{D}$-glucose, 2 sodium butyrate, and 20 sodium acetate. Patch pipettes (2-3 M $\Omega$ ) were fabricated from Corning 8161 glass tubing and filled with (in mM) $145.6 \mathrm{CsCl}, 0.6 \mathrm{CaCl}_{2}, 2.0$ EGTA, 15.4 glucose, and 5.0 Na-HEPES, pH 7.3. Currents were acquired from epithelial cells in whole-cell configuration using an Axopatch 200B patch-clamp amplifier (Molecular Devices) and digitized using an ITC-16 interface and Pulse 8.6.3 software (InstruTECH/HEKA). Cells were visualized using an Olympus BX50 microscope with differential interference contrast optics. The currents were clamped at $-70 \mathrm{mV}$ and blue light was delivered from a mercury arc lamp and sustained for $5-7$ s using a $40 \times$ water-immersion objective.

Electromyographic recording of VMR to colorectal distension and light stimulation. Visceral sensitivity to colorectal distension (CRD) and light stimuli was measured using protocols detailed previously (Christianson et al., 2010; DeBerry et al., 2015; Sadler et al., 2017). Mice were anesthetized in an induction chamber and then moved to a nose cone administering $2 \%$ isoflurane (vaporized with $95 \% \mathrm{O}_{2} / 5 \% \mathrm{CO}_{2}$ ). An incision was made in the skin of the lower abdomen and two silver wires were implanted in the external oblique abdominal muscle and attached to a differential amplifier (A-M Systems). A grounding electrode was adhered to the tail using Signagel (Parker Laboratories). A custom-made laserballoon device was inserted through the anus. This device contains polyethylene tubing (diameter, $0.8 \mathrm{~cm}$ ), enclosing an optical fiber $(400 \mu \mathrm{m}$ core; Thor Labs) connected to a $473 \mathrm{~nm}$ laser power source (Laserglow Technologies) with an inflatable $1 \mathrm{~cm}$ plastic balloon on one end. After electrode implantation and balloon insertion, the level of isoflurane was lowered to $1.5 \%$ and then lowered by $0.125 \%$ every $10 \mathrm{~min}$, down to $0.8 \%$. Toe-pinch reflex was tested as isoflurane was slowly lowered until mice were responsive to toe pinch but were not ambulating. Once a steady level of anesthesia was reached, CRD testing began. CRD was produced by inflating the balloon with air from a compressed nitrogen tank equipped with a pressure regulator and a separate pressure monitor used to regulate the pressure inside of the balloon. EMG signals (indicative of VMR) were amplified, filtered, recorded using Spike2 software (CED), and saved to a PC. Initial $60 \mathrm{mmHg}$ distensions were delivered every 4 min until mice displayed consistent responses to CRD. An additional three distensions were then applied, at $10 \mathrm{~s}$ each, with a 4 min rest period in between. The laser stimulation was then applied three times, at $20 \mathrm{~s}$ each, with a 4 min break between stimuli.

Colorectal responses were quantified by measuring the area under the curve (AUC) for the entire distension or laser period and then subtracting the baseline AUC before application of the stimulus. These measures were then normalized to baseline.

Experimental design and statistical analysis. For single-fiber experiments, the mean values measured in firing properties between two groups (e.g., TRPV1-ChR2 vs Vil-ChR2, homozygous vs heterozygous mice, or nonstretch-sensitive fibers and stretch-sensitive fibers) were compared using unpaired two-tailed $t$ tests with $p<0.05$. Analysis of distension and laser VMR data across control, TRPV1-ChR2, and Vil-ChR2 groups was performed using nonparametric Kruskal-Wallis and Mann-Whitney tests. The number of animals used for each analysis and statistical values are reported in Results. All data were analyzed using Prism software (GraphPad). 


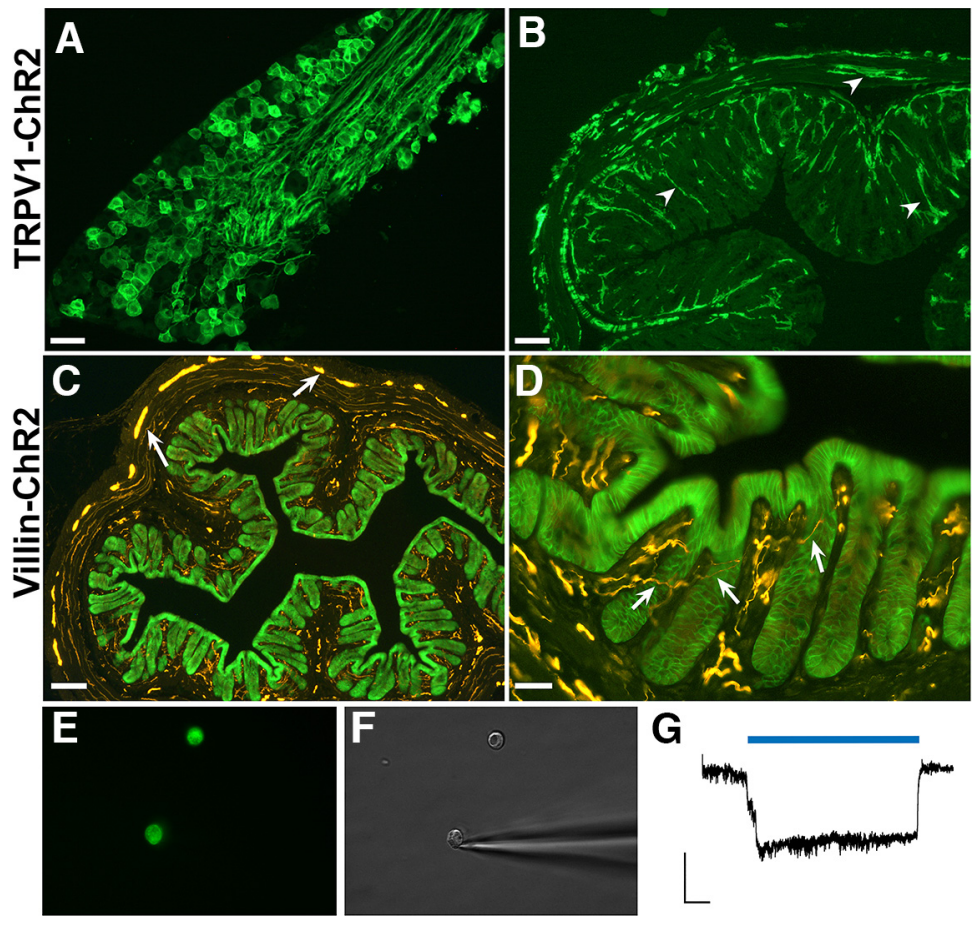

Figure 1. Cell-specific expression of Cre recombinase targets ChR2 to sensory neurons and colon epithelium. A, ChR2-YFP (green)-positive neurons and fibers are present in the L6 DRG of TRPV1-ChR2 mice. $\boldsymbol{B}$, Low-power image shows distribution of ChR2-YFP-positive fibers in the distal colon of TRPV1-ChR2 mice. Arrows indicate nerve bundle in muscular layers and nerve fibers penetrating submucosal layers of the colon. C, ChR2-YFP (green) expression in villin-ChR2 mice is confined to epithelial cells of the colon mucosal layer. Anti-PGP9.5 (yellow) labels nerve fibers that extend into mucosal regions and regions of nerve ganglia in the muscular layer (arrows). D, High-power image illustrates close association between PGP9.5-positive nerve fibers (arrows) and ChR2-YFP labeled epithelial cells. $\boldsymbol{E}, \boldsymbol{F}$, Patch-clamp analysis of dissociated YFP colon epithelial cells show production of inward currents $(G)$ in response to $488 \mathrm{~nm}$ blue-light stimulation. YFP + cell diameter diameters were $\sim 5 \mu \mathrm{m}$. Calibration bars: $\boldsymbol{A}, \boldsymbol{D}, \boldsymbol{F}$, $50 \mu \mathrm{m} ; \boldsymbol{B}, E, 200 \mu \mathrm{m} ; C, 20 \mu \mathrm{m} ; \mathbf{G}, 50 \mathrm{pA}, 1 \mathrm{~s}$.

\section{Results}

Robust expression of ChR2-EYFP is produced using neuronal and colon epithelial-specific Cre recombinase drivers

We examined expression of the ChR2-EYFP fusion protein in DRG sensory neurons and distal colon epithelial cells using TRPV1-ChR2 and villin-ChR2 mice, respectively. Many ChR2-YFPpositive neurons were present in DRG of TRPV1-ChR2 mice (Fig. $1 A$ ), including those with afferents that project to the colon (Fig. $1 B)$. Previous analysis of the TRPV1-Cre mouse line showed that transgene expression occurs in the majority of C-fibers and a subset of A $\delta$ primary afferent neurons (Cavanaugh et al., 2011). This distribution is broader than that seen for TRPV1 in wildtype adult DRG because many neurons express TRPV1 during embryonic development (which would activate the Crerecombinase) but downregulate expression postnatally (Cavanaugh et al., 2011).

In colon tissue of TRPV1-ChR2 mice, ChR2-EYFP-positive fibers were observed in muscular and mucosal layers of the organ (Fig. 1B). TRPV1 expression has been reported in a subset of vagal afferents (Patterson et al., 2003; Bielefeldt et al., 2006; Taylor-Clark et al., 2008) and thus, some of these endings could be vagal (Berthoud et al., 1990, 1991; Wang and Powley, 2000). In addition, there are reports of occasional TRPV1-expressing neurons in the myenteric plexus (Matsumoto et al., 2012; Buckinx et al., 2013) but in general, TRPV1-expressing neurons within the enteric nervous system are rare (Sharrad et al., 2015).

Cre-recombinase expression, driven by the promoter of the actin binding protein villin, targeted ChR2 expression to epithe- lial lining cells of the colon (Fig. 1C,D). YFP labeling indicated expression occurred in all lining epithelial cells but not in other cell types within the colon (e.g., immune, vascular, mesenchymal), cells within the enteric nervous system, or DRG afferents (data not shown). To ensure epithelial cells were responsive to blue light, patch-clamp analysis of YFP-positive cells isolated from enzymatically dissociated colon was carried out. YFP-labeled cells, but not unlabeled cells, showed membrane depolarization in response to blue light, indicating light-activation of the membrane localized ChR2 ion channel (Fig. 1E-G).

As colon tissue from homozygous mice showed higher levels of ChR2 mRNA relative to heterozygotes (determined using reverse transcriptase real time PCR) and this increase correlated with stronger physiologic responses (data below), the majority of experiments were conducted on mice homozygous for the ChR2 transgene. The number of Cre alleles did not affect the response to light-activation of primary afferents or epithelium.

\section{Expression of ChR2-YFP does not change intrinsic firing properties of colon afferents}

A total of 207 colon primary afferents (light-responsive and nonlight-responsive) were recorded from TRPV1-ChR2 (69 fibers) and villin-ChR2 (138 fibers) mouse lines. There were no obvious effects of transgene expression on normal sensory responses (i.e., to brushing, probing, or stretching). For stretch, single colon-afferent fibers in both TRPV1-ChR2 mice and villin-ChR2 mice exhibited no significant difference in the $\mathrm{IF}_{\mathrm{avg}}$ in response to circumferential distension [firing (spike) frequency of TRPV1ChR2 colon afferents, $4.74 \pm 0.83 \mathrm{~Hz}(n=28)$ vs villin-ChR2 colon afferents, $5.91 \pm 0.66 \mathrm{~Hz}(n=50) ; p=0.28, t=1.09]$.

\section{Activation of ChR2 in TRPV1-colon afferents partially} phenocopies responses to natural stimuli

Electrophysiological recordings of teased fibers from the PN of TRPV1-ChR2 mice were used to compare colon sensory afferent response to blue light with their response to applied natural stimuli (blunt probing, stroking, stretch). The dissection and ex vivo preparation used for this analysis are described in Materials and Methods and Figure 2, $A$ and $B$. Examples of single-fiber recordings for each afferent type are shown in Figure 2C. From 21 TRPV1ChR2 mice ( 9 males, 12 females), recordings from 69 sensory fibers were obtained. Of these, 60 were blue light-sensitive (86\%; virtually identical to the number of capsaicin responsive colon afferents reported from intracellular recording from L6 colon afferents; Malin et al., 2009). Among the light-responsive fibers, 33 were stretch-sensitive whereas 27 were not (Fig. 3A).

We also noted that the $\mathrm{IF}_{\mathrm{avg}}$ in response to continuous bluelight illumination (at least $10 \mathrm{~s}$ ) was significantly higher in fibers from homozygous $(n=12)$ animals compared with their heterozygous $(n=38)$ littermates (homozygous $5.49 \pm 1.31 \mathrm{~Hz}$ vs heterozy- 
A

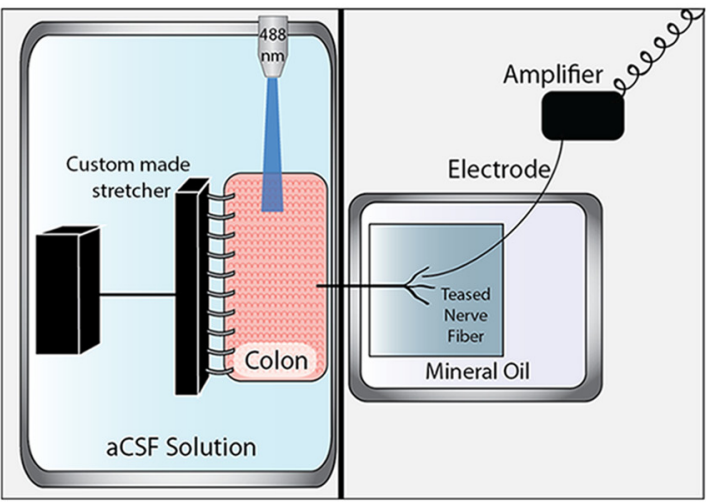

B

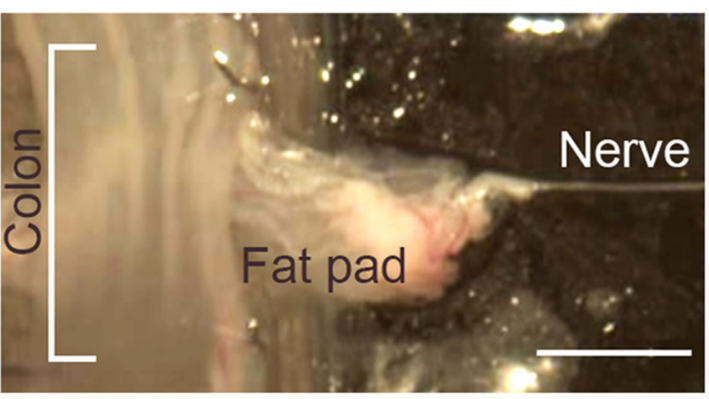

C

Mucosal

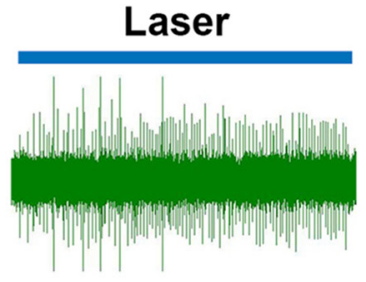

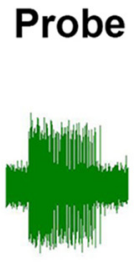

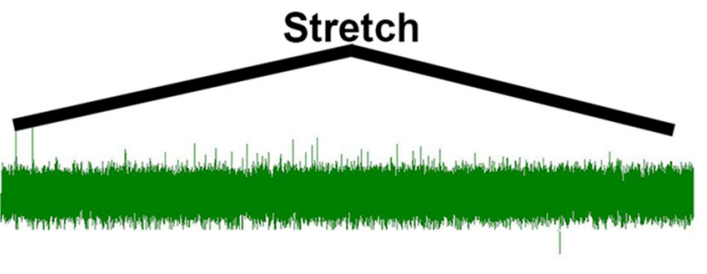

Stretch

Brush
Muscular

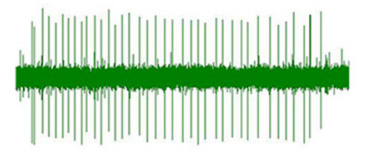

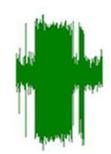
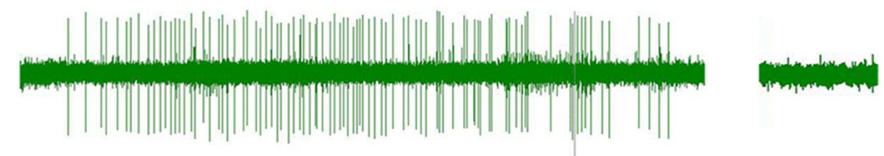

\section{Muscular/ Mucosal}
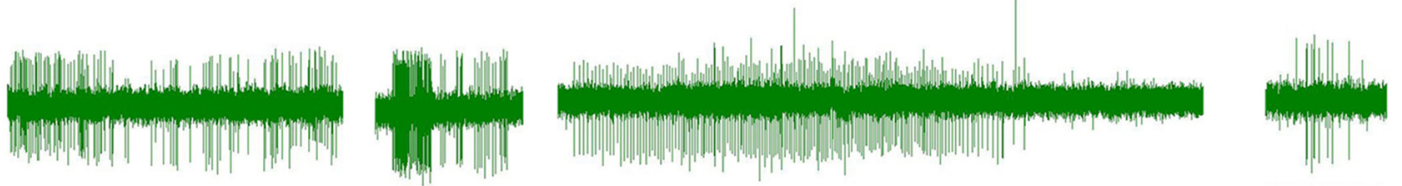

\section{Serosal}
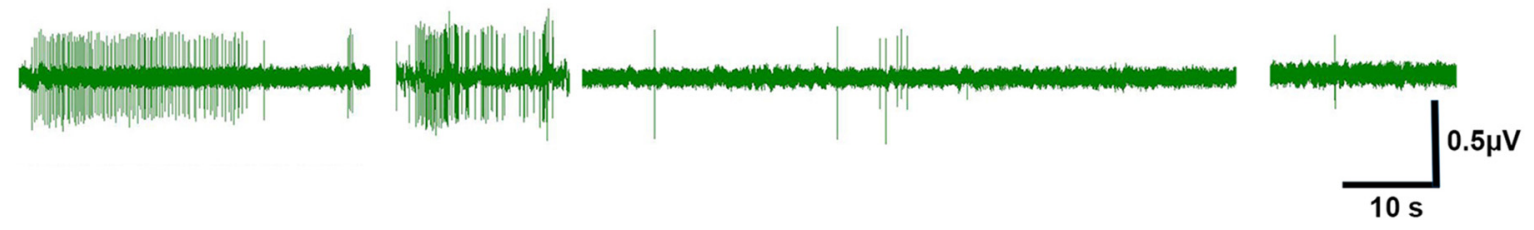

Figure 2. Examples of teased fiber recordings from TRPV1-ChR2 mice show activation of all fiber types in response to blue light. $A$, Diagram illustrates the components of the ex vivo preparation used to obtain single-fiber recordings of colon afferents. $\boldsymbol{B}$, Image shows colon tissue with attached fat pad and pelvic nerve from which recordings were made. $\boldsymbol{C}$, All classes of mechanically sensitive colon afferents (mucosal, muscular, muscular/mucosal, and serosal) exhibited robust action potential firing in response to blue laser light. Scale bar, $4 \mathrm{~mm}$.

gous $3.3 \pm 0.45 \mathrm{~Hz} ; p=0.05, t=2.02)$, which suggests that increased expression and membrane insertion of the ChR2 protein leads to enhanced afferent firing.

Afferent responses to blue light in TRPV1-ChR2 preparations produced variable firing patterns that were not unique to fiber type. Patterns ranged from firing in single or multiple bursts to continuous tonic firing (Fig. 2C). The average firing rate and latency to fire in response to light onset was similar for stretch and non-stretch-sensitive fibers $\left[\left(\mathrm{IF}_{\mathrm{avg}}=3.8 \pm 0.57 \mathrm{~Hz}\right.\right.$ (stretchsensitive, $n=28$ ) vs $3.86 \pm 0.82 \mathrm{~Hz}$ (non-stretch-sensitive, $n=$ 22); $p=0.95, t=0.06$; latency to first spike $=0.4 \pm 0.17 \mathrm{~s}$ (stretch-sensitive, $n=27$ ) vs $0.28 \pm 0.15$ s (non-stretch-sensitive, $n=20) p=0.62, t=0.5)]$.

The ability of TRPV1-ChR2 fibers to follow pulsed blue light was also assessed at 1, 5, 10, and $20 \mathrm{~Hz}$ in 24 fibers. All TRPV1ChR2 fibers that did respond to light were able to fire action potentials at $1 \mathrm{~Hz}$, but the number of action potentials decreased with increasing frequency. At $1 \mathrm{~Hz}, 86.4 \%$ of the $50 \mathrm{~ms}$ light pulses induced action potentials in all afferents. With increasing fre- quency this percentage decreased to $20.7 \%$ at $20 \mathrm{~Hz}$ (Table 1). This pattern was observed across all fiber types.

Optogenetic activation of $\mathrm{ChR} 2$ in colon epithelial cells generates action potentials in primary afferent fibers

Using the ex vivo colon preparation we then determined the effect of light activation of ChR2 in epithelial cells on DRG afferent firing. Teased fiber analysis of the pelvic nerve showed that blue light generated robust action potential firing in DRG sensory fibers, similar to responses elicited by stretch stimulation (Fig. 4). Responses of teased fibers to mechanical or blue-light stimulation were recorded in preparations from 27 villin-ChR2 mice (14 males, 13 females; $n=138$ fibers). Comparison of response properties of light-sensitive and light-insensitive fibers showed no difference in the $\mathrm{IF}_{\mathrm{avg}}$ for circumferential stretch in stretch-sensitive afferents [light-sensitive $\left(n=8\right.$; mean stretch $\left.\mathrm{IF}_{\text {avg }} 4.52 \pm 1.04\right)$ vs light-insensitive afferents $\left(n=42\right.$; mean stretch $\operatorname{IF}_{\text {avg }} 6.18 \pm$ $0.75, p=0.36, t=0.92)] . \mathrm{IF}_{\text {avg }}$ values for blunt probing were also similar between light-sensitive and light-insensitive serosal affer- 


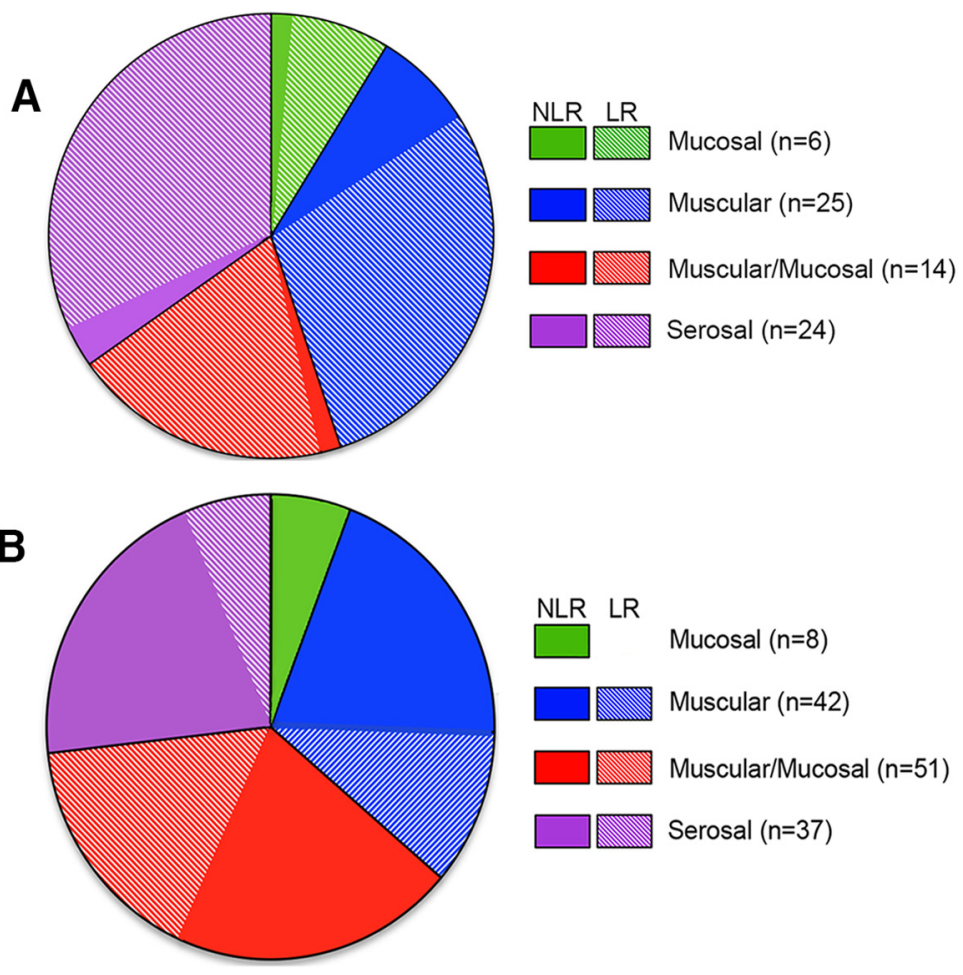

Figure 3. Distribution of blue light-responsive (LR) and non-light-responsive (NLR) fiber types in TRPV1-ChR2 and villin-ChR2 mice. $A, 0$ f 69 sensory fibers recorded from TRPV1-ChR2 mice ( $N=20$ mice), $86 \%$ were responsive to blue light. Of the 69 fibers, 39 were stretch-sensitive (muscular or muscular/mucosal) and 30 were not stretch-sensitive (mucosal and serosal). $\boldsymbol{B}$, For villinChR2 mice $(N=27)$ a total of 138 fibers were characterized and of these, $50(36 \%)$ were responsive to blue-light activation of colon epithelium.

ents (those afferents that did not respond to stretch but did respond to probing: light-sensitive, $n=9$, mean probe $\mathrm{IF}_{\mathrm{avg}}$ $21.76 \pm 4.11$ vs light-insensitive, $n=13$, mean probe $\mathrm{IF}_{\mathrm{avg}} 21.6 \pm$ 3.52; $p=0.98, t=0.03$ ).

The increased level of ChR2 mRNA in homozygous villinChR2 mice, as indicated by RTPCR measures, translated to increased fluorescent intensity of ChR2-EYFP expression in the colon. Colon preparations from homozygous villin-ChR2 mice also had a greater percentage of action potentials generated in response to epithelial activation; $50.5 \%$ of fibers recorded from villin-ChR2 homozygous mice (46/91) responded to light compared with $8.5 \%(4 / 47)$ in heterozygous mice.

Of the 50 fibers that responded to light stimulation of colon epithelium, 38 were stretch-sensitive (i.e., muscular and muscular/mucosal subtypes; Fig. 3B). Evoked responses had a wide range of latencies (0.03-60.3 s, mean $15.5 \pm 2.09$ s; Fig. 5), and the majority of responses exhibited robust firing that adapted over time. Comparison of stretch-sensitive and stretch-insensitive (serosal) afferents in which firing latency to light could be accurately measured, showed that action potentials elicited in stretch-sensitive fibers $(n=27)$ had shorter latencies (latency $=12.2 \pm 1.98$ vs $24.03 \pm 6.14, p=0.02, t=2.43)$ and higher $\mathrm{IF}_{\text {avg }}$ values $(5.37 \pm$ 0.56 vs $3.13 \pm 0.97, p=0.058, t=1.96)$ compared with nonstretch-sensitive fibers $(n=8)$.

Interestingly, of the four types of extrinsic colon afferents, light activation of the epithelium produced robust action potential firing in all but mucosal afferents (Fig. $3 B$ ). This was surprising given that this type of fiber, identified by its ability to respond exclusively to light brushing of the epithelium, is thought to terminate in or nearby the colonic epithelium and therefore should be in an ideal location to respond to activation of ChR2 in the epithelium. It should be noted that this anatomical relationship is only inferred based on stimulus response properties; there are no reports in which anatomical features have been determined for physiologically characterized afferents. Thus, mucosal fibers may communicate with the epithelium in a manner that is unique from other types of extrinsic afferents (and one not engaged by ChR2 activation) and/or their ability to respond to brushing of the epithelium is via mechanical sensory transducers intrinsic to this population of afferents in a manner that does not rely on communication with the epithelium.

Afferent firing rates in response to light stimulation of epithelial cells was similar to rates recorded from TRPV1-ChR2 afferents [mean villin: $\mathrm{IF}_{\mathrm{avg}}=4.86 \pm 0.5 \mathrm{~Hz}$ $(n=35)$ vs TRPV1: $3.83 \pm 0.48 \mathrm{~Hz}(n=$ 50), respectively; $p=0.15, t=1.46]$. However, there was a significantly longer latency for the first action potential with light-activation of villin-ChR2 epithelial cells than that measured for light activation of TRPV1-ChR2 colon afferents [latency: villin $14.9 \pm 2.2 \mathrm{~s}(n=35)$; TRPV1 $0.35 \pm 0.12 \mathrm{~s}(n=47) ; p<0.0001, t=$ 7.67; compare Figs. $2 C, 4]$. In addition, the latency of afferent firing in villinChR2 mice increased with repeated light stimulation.

Interestingly, when comparing afferent firing induced by light activation of epithelial cells to that induced by natural stimuli (stretch) in the same fiber, the latencies to first action potential were not significantly different [stretch-sensitive fibers $(n=8)$, latency in response to light $=4.73 \pm 1.07 \mathrm{~s}$; latency in response to stretch $=4.52 \pm 1.04 \mathrm{~s}, p=0.89, t=0.14]$. This suggests that the mechanism(s) underlying epithelial activation of colon afferents shares temporal characteristics with those for stretch induced activation. Thus, epithelial activation could be a contributor to stretch-induced afferent activation.

\section{Antagonism of ATP signaling inhibits stretch and light-induced afferent firing}

The increased latency of firing in generation of action potentials by light-mediated activation of epithelial cells suggests that communication to nerve fibers occurs through release of a chemical mediator(s). To explore this possibility we bath applied an ATP antagonist drug mixture (PPADS, TNP-ATP, and AR-C118925XX) to the preparation and assessed firing properties. In response to a ramp stretch stimulus, 4 of 6 (66.7\%) TRPV1-ChR2 stretchsensitive fibers had reduced responses in the presence of drug mixture (Fig. 6). No fibers showed complete inhibition of firing with drug application. The ability of the ATP antagonist mixture to block the response to light stimulation of the epithelium was also tested in 11 fibers of villin-ChR2 mice. Of these, $8(72.7 \%)$ responded to drug application, which is comparable to the inhibitory effects on the TRPV1-ChR2 stretchsensitive fiber population (Fig. 6). All fibers tested were stretch-sensitive. Of the eight drug-sensitive fibers, $37.5 \%$ (3/8) had a complete block in firing, whereas $62.5 \%(5 / 8)$ had a partial block to drug application. 
Table 1. TRPV1-ChR2-expressing fibers were exposed to 20 light pulses (50 ms each) at 1, 5, 10, and $20 \mathrm{~Hz}$ and the number of action potentials generated were recorded

\begin{tabular}{lcccc}
\hline & $1 \mathrm{~Hz}(n=24)$ & $5 \mathrm{~Hz}(n=23)$ & $10 \mathrm{~Hz}(n=9)$ & $20 \mathrm{~Hz}(n=12)$ \\
\hline $\begin{array}{l}\text { Light pulses that generate an action } \\
\text { potential, \% (avg) }\end{array}$ & $86.4 \%$ & $50.3 \%$ & $24.4 \%$ & $20.7 \%$ \\
& $5.0 \mathrm{~s}$ & $\mathbf{1 . 0 \mathrm { s }}$ & $\mathbf{0 . 5 \mathrm { s }}$ &
\end{tabular}

At $1 \mathrm{~Hz}$ stimulation most (86.4\%) fibers generated action potentials for each of the 20 light pulses. At higher-stimulation frequencies, afferents produced fewer action potentials during the stimulus train. Not all fibers were tested at all frequencies. $n=$ number of fibers recorded at each frequency.

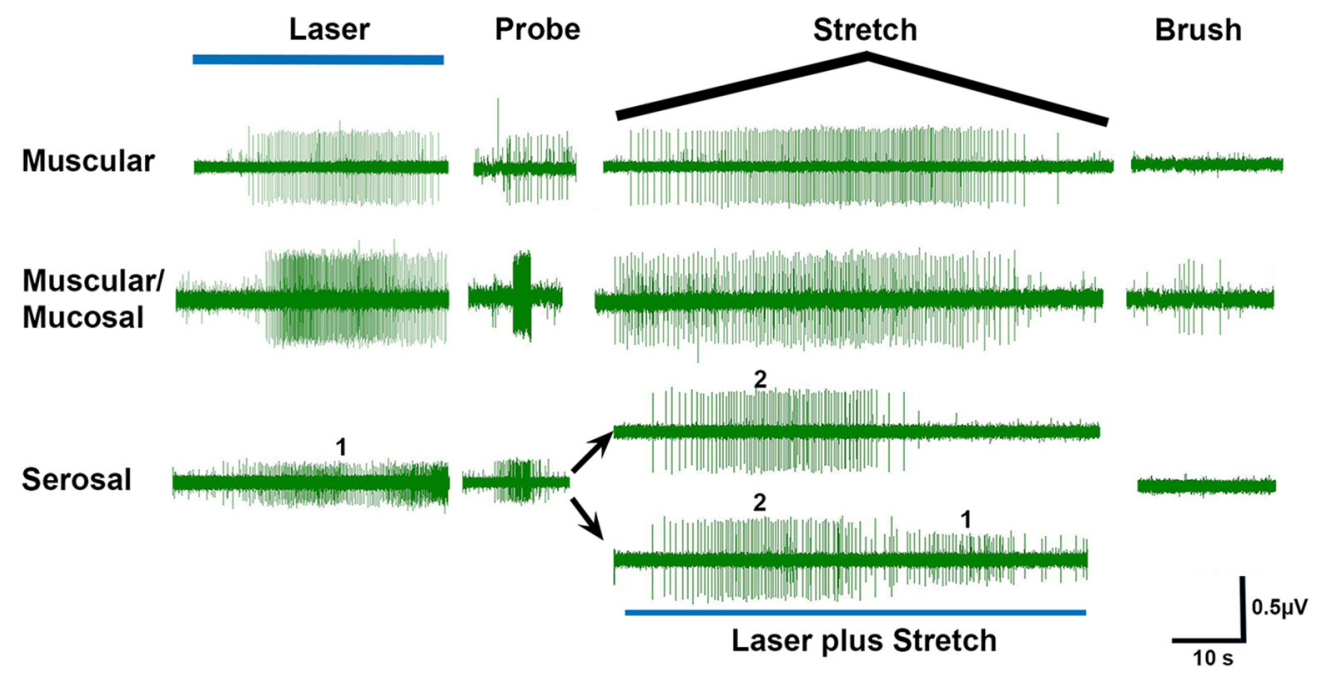

Figure 4. Examples of teased fiber recordings from villin-ChR2 mice show activation of all fiber types in response to blue light. With the exception of mucosal afferents, all classes of mechanically sensitive colon afferents are blue light-sensitive. In the example provided for serosal afferents, two fibers were recorded together. One fiber was classified as serosal and light responsive, due to its responses to probe and laser stimulation (1). A second fiber was sensitive to stretch stimulation but not light (2). The two different fibers are apparent in the bottom trace, where stretch and laser are applied at the same time.

Light activation of colon epithelium elicits behavioral responses To determine whether activation of ChR2 in colon epithelial cells engages neural signaling pathways in vivo, we assessed behavioral responses to colon distention and light activation in anesthetized animals. Measures of the VMR were obtained as a surrogate for sensory-induced activation of the colon neural circuitry. Colon distension, via computer-controlled inflation of a balloon in the distal colon, was combined with laser illumination of the colon via a fiber optic contained within the balloon. In littermate control mice ( 4 male, 2 female), balloon distension to $60 \mathrm{mmHg}$ induced a strong VMR response (Fig. 7A) but no change in VMR in response to light illumination of the colon (Fig. $7 B$ ). As a positive control for ChR2 activation of sensory neurons, TRPV1ChR2 mice were tested ( 1 male, 3 female). As expected, TRPV1ChR2 mice exhibited a strong VMR in response to light activation similar to that evoked with balloon distention of the colon (Fig. $7 C)$. For Vil-ChR2 mice ( 4 male, 1 female), light activation of ChR2 in the epithelium also produced robust and reproducible VMRs (Fig. 7D). Comparison of the response rate to light stimuli shows that relative to control littermates ( $n=6$ mice), a significant increase occurs in the percentage of responses for both TRPV1-ChR2 ( $p=0.005, n=4)$ and Vil-ChR2 ( $p=0.038$, $n=5)$ groups. There was no difference in the percentage of response between TRPV1-ChR2 and Vil-ChR2 groups (Fig. 7E). The average VMR values for the TRPV1-ChR2 and Vil-ChR2 groups also were significantly greater relative to the control group (TRPV1-ChR2, $P=0.006$; Vil-ChR2, $p=0.043$; Kruskal-Wallis test), but there was no difference between the two ChR2-expressing mouse lines (Fig. $7 F$ ).
Finally, though the response rates were not significantly different between the TRPV1 and Vil-ChR2 groups, the latency to respond was significantly faster in TRPV1-ChR2 mice [latency Vil-ChR2, $7.9 \pm 1.9 \mathrm{~s}(n=6$ mice $)$ vs TRPV1-ChR2, $0.31 \pm 0.2 \mathrm{~s}$ ( $n=4$ mice); $P=0.010, t=3.957$; unpaired $t$ test with Welch's correction]. This difference well parallels the increased latency of firing measured using the teased fiber preparation and likely reflects the more direct activation of ChR2 in afferent terminals versus the epithelium.

\section{Discussion}

Results from this study show that ChR2-mediated activation of colon epithelium can directly engage neural circuitry involved in regulating neural pathways critical for colon function. Results of teased fiber analysis of an intact colon preparation and in vivo measures of VMRs in response to light stimuli indicate that selective activation of epithelial cells generates action potentials in extrinsic primary afferents that have functional consequences. Epithelial-nerve communication was evident across all functional subtypes of colon afferents with the exception of mucosal afferents. The absence of this fiber type may be due to the small number of mucosal sensory neurons sampled by our study ( 6 of 138 total fibers). The response parameters of sensory fibers activated by light/epithelial stimulation were often similar to those elicited by mechanical stimulation (designed to mimic natural stimuli). Importantly, the neuronal response to light stimulation of epithelial cells could be blocked or diminished in the majority of responsive sensory fibers with the application of a mixture of ATP receptor antagonists. These results indicate that the 

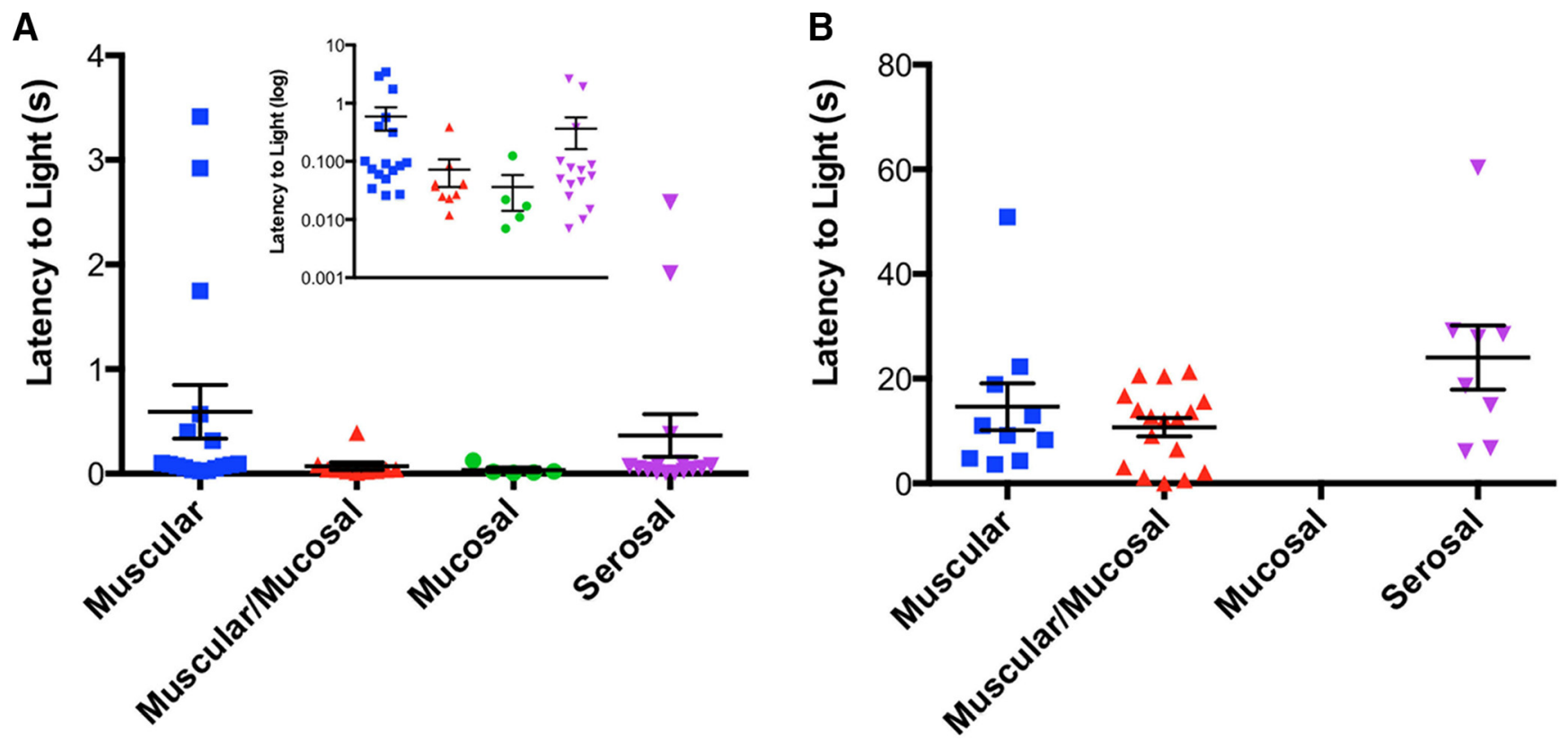

Figure 5. Afferents of TRPV1-ChR2 and villin-ChR2 mice have different latencies to blue-light stimulation. $A$, Nearly all mechanically sensitive afferents from TRPV1-ChR2 mice had firing latencies (time between start of light stimulus and afferent firing) $<1 \mathrm{~s}(\mathrm{avg}=0.35 \mathrm{~s}$ ). Inset, Log plot of values on an expanded scale. $\boldsymbol{B}$, Mechanically sensitive fibers from villin-ChR2 mice exhibit much longer latencies (avg $=14.9 \mathrm{~s})$ in response to light activation of the epithelium. Mucosal fibers that respond to light activation were rare compared with all other fiber types.
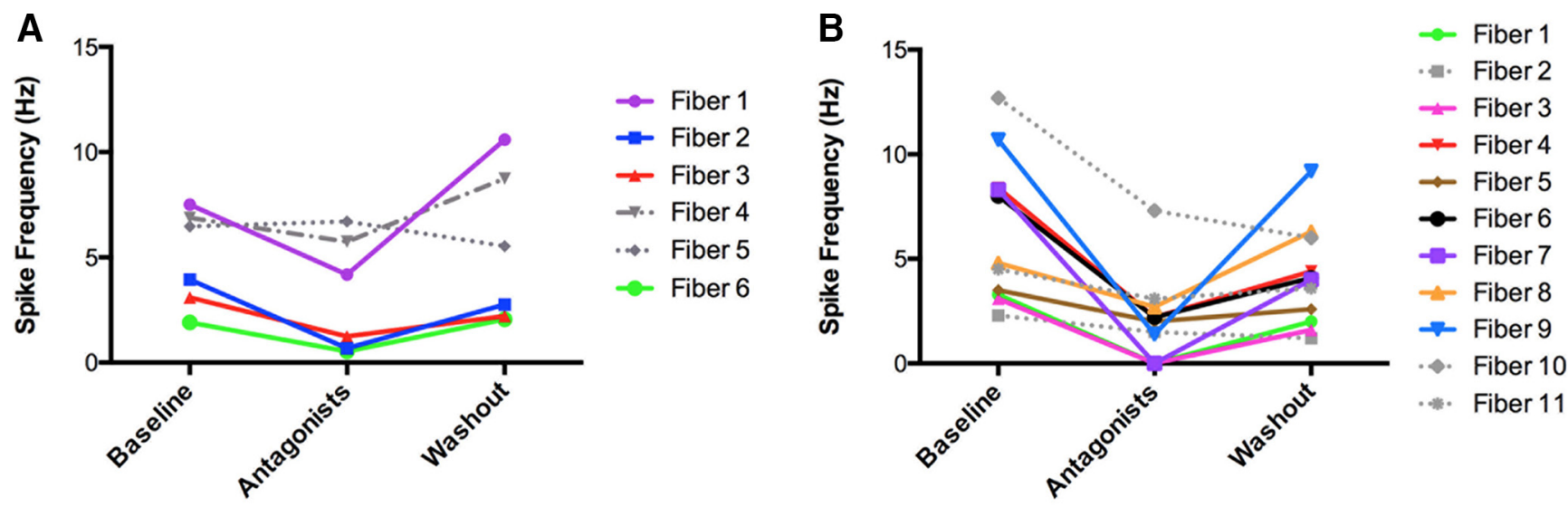

Figure 6. Antagonism of ATP signaling causes reduction in firing to stretch and light stimuli. A drug mixture containing PPADS, TNP-ATP, and AR-C118925XX was used to block responses to stretch $(\boldsymbol{A})$ or laser $(\boldsymbol{B})$ stimuli. Response to the drug mixture was defined as a $\geq 25 \%$ reduction in average firing rate upon drug application and a recovery of firing rate by $\geq 25 \%$ upon washout. Gray dotted lines in each graph represent nonresponders. $\boldsymbol{A}$, Fiber responses to stretch were recorded at baseline, in the presence of the antagonist mixture, and after a 10 min washout. Four of six fibers tested (66.7\%) responded to the antagonist mixture and showed reduction in spike frequency in response to stretch. $\boldsymbol{B}$, In villin-ChR2 mice, fibers that were identified as stretch-sensitive were also evaluated. Fiber responses to laser stimulation of colon epithelium were recorded at baseline, in the presence of the antagonist mixture, and after a 10 min washout. Application of the ATP antagonist mixture caused a reduction in firing frequency to light in 8 of the 11 fibers tested (72.7\%).

intestinal epithelium alone, e.g., without additional mechanical stimuli, can directly activate colon sensory afferents and that ATP is likely to have a critical role in this epithelial cellnerve communication.

Light activation of epithelial cells was sufficient to cause firing in afferents functionally classified as muscular, muscular/mucosal, and serosal. Because fiber classifications were made based on responses to stroking, probing, and stretch, as is standard in the field, the exact anatomical location of these endings is not known. For example, anatomical tracing studies (Song et al., 2009; Spencer et al., 2014) find no evidence of fibers that actually end in the serosa, making the terminology misleading. This makes it difficult to accurately define a mechanistic link between epithelial activation and firing in afferent types, e.g., muscular and serosal.
With this limitation in mind, one mechanism of activation could involve an intermediary cell; for example, a neuron in the submucosal and/or myenteric plexus that has projections near the epithelium. In this scenario, the location of a responsive afferent relative to the epithelium would not matter, provided that it connects with another neuron(s) that is near the mucosa. A synaptic delay might, in part, explain the longer latency to firing that follows laser exposure when ChR2 is expressed in the epithelium compared with when it is expressed within the sensory fiber itself. There is also the question as to whether a response to brushing really means that the fiber is terminating at the mucosa. It is entirely possible that this response simply represents a colon afferent with a very low mechanical threshold whose termination could be in more distant layers. 
The epithelium has long been implicated as a modulator of neural activity. A recent example comes from Bellono et al. (2017) in which application of norepinephrine to the mucosa was shown to induce action potential firing in mucosal afferents that could be blocked by $5 \mathrm{HT}_{3}$ receptor antagonism. Bellono et al. (2017) also showed that a subset of colon epithelial cells, enterochromaffin cells, which are electrically excitable, express voltage-gated ion channels and release 5-HT in response to depolarization.

Of particular relevance for the present work is the purinergic mechanism hypothesis, in which Burnstock (2001) proposed that intestinal epithelial cells release endogenous ATP in response to stretch. This hypothesis proposed that released ATP activates $\mathrm{P} 2 \mathrm{X}_{3}$ or $\mathrm{P} 2 \mathrm{X}_{2 / 3}$ receptors localized on extrinsic afferent terminals, resulting in increased firing (Burnstock, 1999, 2001, 2013). Using an ex vivo preparation of rat colorectum, Wynn et al. (2003) provided support for this hypothesis by showing that serosal application of ATP could activate mechanosensitive extrinsic afferents, increasing their peak responses. However, missing from these previous studies is direct evidence that activation of the colonic epithelium can produce action potentials de novo in extrinsic primary sensory neurons, e.g., without simultaneous mechanical stimuli. Until the advent of optogenetic tools these data have been difficult to obtain since it was not possible to stimulate colonic epithelium without also engaging putative transduction mechanisms resident in sensory fibers themselves, i.e., because of the intimate anatomical relationship of the colonic epithelium and the nerves innervating these cells, mechanical, chemical, or thermal stimulation could not be applied without simultaneously affecting both compartments. The selective expression of opsin genes by tissue-specific gene promoters as used here allows specific activation of epithelial cells.

As seen in cutaneous sensory neurons (Baumbauer et al., 2015), light activation of ChR2 expressed in colon afferents (i.e., in TRPV1-ChR2 mice) did not completely mimic the response to naturalistic colon stimuli (i.e., stretch or probing). As in cutaneous afferents, light activation of ChR2 in colon afferents produced almost instantaneous action potentials and continuous exposure to $473 \mathrm{~nm}$ light produced repetitive firing with relatively stable instantaneous frequency (although desensitization was seen at longer exposure times). This pattern of action potential firing differs from the patterns observed when action potentials were induced by light activation of the colon epithelium; for epithelium, neuronal firing patterns were much more complex and often similar to those produced by mechanical stimulation of the colon. These more complex patterns of neuronal activation included variable delays in the onset of firing, which
B

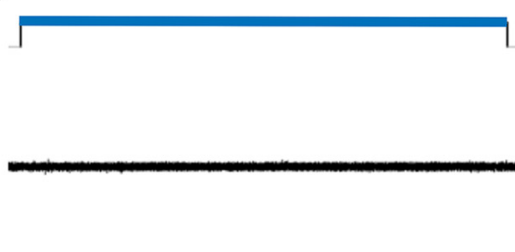

D

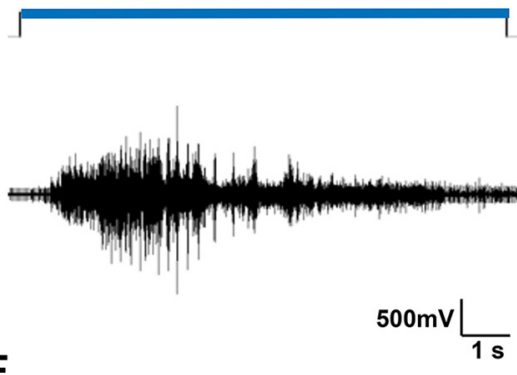

$\mathbf{F}$

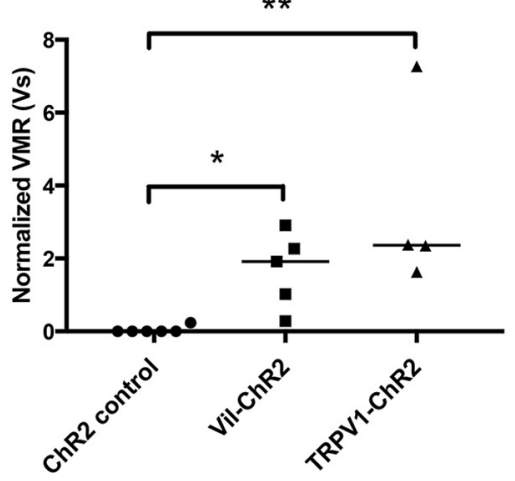

Figure 7. In vivo light-mediated activation of colonic epithelium generates visceromotor responses. $A$, VMRs to noxious colon distention ( $60 \mathrm{mmHg}$ ) were elicited in all mouse strains analyzed: Vil-ChR2, TRPV1-ChR2 and littermate controls. Example shown is a recording from a control mouse. $\boldsymbol{B}$, In control mice, blue-light stimulation produces no VMR in response. $\boldsymbol{C}$, In TRPV1-ChR2 mice, $\mathrm{mmHg}$ of balloon pressure. D, Vil-ChR2 mice exhibit robust VMRs in response to blue-light stimulation of ChR2 expressed in 政, baseline measures from individual animals. Asterisks indicate significant increases relative to control group for TRPV1- and VilChR2 groups. There was no difference in VMRs between TRPV1- and Vil-ChR2 groups.

were comparable to delays that occur during the induction of circumferential stretch and included high-frequency bursting and desensitization. The relatively long delay in afferent activation following light stimulation of the epithelium may reflect multiple factors. First, the intestinal epithelium is constantly moving upward from the stem-cell zone in the crypts toward the lumen as part of the dynamic process of epithelial cell turnover (Heath, 1996; Chen et al., 2001). As a result, the anatomic relationship between the epithelial cells and the more static neuronal terminals varies at any given point in time (Chen et al., 2001) making it likely that any neuromodulatory substance released by epithelial cells may have significant distances to diffuse before encountering neurotransmitter receptors on sensory endings. Another possibility is that epithelial activation releases activators that stimulate other cells in colon tissue, including immune cells or neurons in the enteric nervous system, that subsequently release neurotransmitters that activate extrinsic colon afferents. 
As previous data show that epithelial-released ATP may modulate colon afferent activity (Wynn et al., 2003, 2004; Ueda et al., 2009), we further investigated epithelial-nerve signaling by combining ATP antagonists with light stimulation of the epithelium. As a positive control, we were able to confirm that ATP is involved in modulation of action potentials in colon afferents in response to physiologic stretch by demonstrating that ATP receptor antagonists reduce firing during a ramp stretch. A similar decrease in firing was seen when the same ATP antagonists were combined with light activation of ChR2-expressing epithelial cells, supporting the hypothesis that colonic epithelium can directly initiate action potentials in colon afferents via the release of ATP. It should be noted that although some epithelial-induced firing of colon afferents was completely blocked by our ATP antagonist mixture, most fibers exhibited only partial reduction in firing. This suggests that additional mechanisms are likely involved in neuronal activation. In addition, our drug mixture of ATP antagonists targeted ATP receptors known to be expressed in colonic afferents, including $\mathrm{P}_{2} \mathrm{X}_{2 / 3}$ and $\mathrm{P}_{2} \mathrm{Y}_{2}$ (Giaroni et al., 2002; Robinson et al., 2004; Brierley et al., 2005; Shinoda et al., 2010). However, Hockley et al. (2016) recently described the expression of additional $\mathrm{P} 2 \mathrm{Y}$ receptors including $\mathrm{P} 2 \mathrm{Y}_{1}, \mathrm{P} 2 \mathrm{Y}_{4}, \mathrm{P}_{2} \mathrm{Y}_{12}$, and $\mathrm{P} 2 \mathrm{Y}_{13}$ on colon afferents (although $\mathrm{P} 2 \mathrm{Y}_{12}$, and $\mathrm{P} 2 \mathrm{Y}_{13}$ are $\mathrm{Gi}_{\%}$ GPCRs and therefore likely to be inhibitory). Hockley et al. (2016) found that $\mathrm{P}_{2} \mathrm{Y}_{1}$, an excitatory receptor that binds ADP (a rapid metabolite of ATP) and UTP, was expressed in a majority of dissociated colon sensory neurons. Our studies used PPADS, but at a concentration that may not completely block $\mathrm{P} 2 \mathrm{Y}_{1}$, and therefore, some of the afferent activity not blocked following ChR2 activation of the epithelium could be due to binding of either ADP or UTP to P2 $\mathrm{Y}_{1}$ expressed on colon afferents. Also to be considered is that colonic primary afferents express several additional ligandmediated excitatory channels including TRPV1 (Sugiuar et al., 2004; Brierley et al., 2005; Malin et al., 2009, 2011; Matsumoto et al., 2009), TRPA1 (Brierley et al., 2009; Christianson et al., 2010; Engel et al., 2011; Malin et al., 2011), TRPM8 (Mueller-Tribbensee et al., 2015), and 5- $\mathrm{HT}_{3}$ and 5- $\mathrm{HT}_{4}$ receptors (Hicks et al., 2002; Coldwell et al., 2007; Feng et al., 2012; Gershon, 2013; Mawe and Hoffman, 2013).

The present study fills a major gap in the purinergic hypothesis in that it shows using an intact preparation that it is possible to stimulate colonic epithelium without stimulating any surrounding cells, including neurons. This stimulation produces robust firing of colon extrinsic sensory neurons in a manner that is at least partially ATP dependent. However, numerous questions remain. Studies by Bohórquez and Liddle (2011) and Bohórquez et al. $(2011,2014)$ have revealed molecular and anatomical specializations typically present at synapses (including dense and clear core vesicles) in unique populations of neuroendocrine cells in the colon and that these specializations are found adjacent to colon sensory afferents. Although these cells represent a minority of colonic epithelial cells, they provide a "proof of concept" for the type of structure that could be responsible for the epithelialbased activation of colon afferents described here. However, it is important to note that other authors provide evidence that stretchevoked activation of colon afferents is $\mathrm{Ca}^{2+}$-independent (Zagorodnyuk et al., 2005), indicating that vesicular release (which is typically $\mathrm{Ca}^{2+}$ dependent) is not an essential requirement for mechanotransduction. Thus, further work is necessary to identify the mechanism underlying epithelial-nerve communication and to better understand the role of the colon epithelium in modulation of colon afferent activity under normal and pathologic conditions.

\section{References}

Baumbauer KM, DeBerry JJ, Adelman PC, Miller RH, Hachisuka J, Lee KH, Ross SE, Koerber HR, Davis BM, Albers KM (2015) Keratinocytes can modulate and directly initiate nociceptive responses. eLife 4:e09674. CrossRef Medline

Bellono NW, Bayrer JR, Leitch DB, Castro J, Zhang C, O’Donnell TA, Brierley SM, Ingraham HA, Julius D (2017) Enterochromaffin cells are gut chemosensors that couple to sensory neural pathways. Cell 170:185-198.e16. CrossRef Medline

Berthoud HR, Jedrzejewska A, Powley TL (1990) Simultaneous labeling of vagal innervation of the gut and afferent projections from the visceral forebrain with dil injected into the dorsal vagal complex in the rat. J Comp Neurol 301:65-79. CrossRef Medline

Berthoud HR, Carlson NR, Powley TL (1991) Topography of efferent vagal innervation of the rat gastrointestinal tract. Am J Physiol 260:R200-R207. CrossRef Medline

Bertrand PP (2003) ATP and sensory transduction in the enteric nervous system. Neuroscientist 9:243-260. CrossRef Medline

Bertrand PP (2009) The cornucopia of intestinal chemosensory transduction. Front Neurosci 3:48. CrossRef Medline

Bielefeldt K, Zhong F, Koerber HR, Davis BM (2006) Phenotypic characterization of gastric sensory neurons in mice. Am J Physiol Gastrointest Liver Physiol 291:G987-G997. CrossRef Medline

Bohórquez DV, Liddle RA (2011) Axon-like basal processes in enteroendocrine cells: characteristics and potential targets. Clin Transl Sci 4:387-391. CrossRef Medline

Bohórquez DV, Chandra R, Samsa LA, Vigna SR, Liddle RA (2011) Characterization of basal pseudopod-like processes in ileal and colonic PYY cells. J Mol Histol 42:3-13. CrossRef Medline

Bohórquez DV, Samsa LA, Roholt A, Medicetty S, Chandra R, Liddle RA (2014) An enteroendocrine cell-enteric glia connection revealed by 3D electron microscopy. PLoS One 9:e89881. CrossRef Medline

Bornstein JC (2006) Intrinsic sensory neurons of mouse gut-toward a detailed knowledge of enteric neural circuitry across species: focus on "characterization of myenteric sensory neurons in the mouse small intestine". J Neurophysiol 96:973-974. CrossRef Medline

Brierley SM, Jones RC 3rd, Gebhart GF, Blackshaw LA (2004) Splanchnic and pelvic mechanosensory afferents signal different qualities of colonic stimuli in mice. Gastroenterology 127:166-178. CrossRef Medline

Brierley SM, Carter R, Jones W 3rd, Xu L, Robinson DR, Hicks GA, Gebhart GF, Blackshaw LA (2005) Differential chemosensory function and receptor expression of splanchnic and pelvic colonic afferents in mice. J Physiol 567:267-281. CrossRef Medline

Brierley SM, Hughes PA, Page AJ, Kwan KY, Martin CM, O’Donnell TA, Cooper NJ, Harrington AM, Adam B, Liebregts T, Holtmann G, Corey DP, Rychkov GY, Blackshaw LA (2009) The ion channel TRPAl is required for normal mechanosensation and is modulated by algesic stimuli. Gastroenterology 137:2084-2095.e3. CrossRef Medline

Buckinx R, Van Nassauw L, Avula LR, Alpaerts K, Adriaensen D, Timmermans JP (2013) Transient receptor potential vanilloid type 1 channel (TRPV1) immunolocalization in the murine enteric nervous system is affected by the targeted C-terminal epitope of the applied antibody. J Histochem Cytochem 61:421-432. CrossRef Medline

Burnstock G (1999) Release of vasoactive substances from endothelial cells by shear stress and purinergic mechanosensory transduction. J Anat 194: 335-342. CrossRef Medline

Burnstock G (2001) Purine-mediated signalling in pain and visceral perception. Trends Pharmacol Sci 22:182-188. CrossRef Medline

Burnstock G (2013) Purinergic mechanisms and pain: an update. Eur J Pharmacol 716:24-40. CrossRef Medline

Burnstock G (2014) Purinergic signalling in the gastrointestinal tract and related organs in health and disease. Purinergic Signal 10:3-50. CrossRef Medline

Cavanaugh DJ, Chesler AT, Jackson AC, Sigal YM, Yamanaka H, Grant R, O'Donnell D, Nicoll RA, Shah NM, Julius D, Basbaum AI (2011) Trpv1 reporter mice reveal highly restricted brain distribution and functional expression in arteriolar smooth muscle cells. J Neurosci 31:5067-5077. CrossRef Medline

Chen JJ, Li Z, Pan H, Murphy DL, Tamir H, Koepsell H, Gershon MD (2001) Maintenance of serotonin in the intestinal mucosa and ganglia of mice that lack the high-affinity serotonin transporter: abnormal intestinal mo- 
tility and the expression of cation transporters. J Neurosci 21:6348-6361. CrossRef Medline

Christianson JA, Bielefeldt K, Malin SA, Davis BM (2010) Neonatal colon insult alters growth factor expression and TRPA1 responses in adult mice. Pain 151:540-549. CrossRef Medline

Coldwell JR, Phillis BD, Sutherland K, Howarth GS, Blackshaw LA (2007) Increased responsiveness of rat colonic splanchnic afferents to 5-HT after inflammation and recovery. J Physiol 579:203-213. CrossRef Medline

DeBerry JJ, Saloman JL, Dragoo BK, Albers KM, Davis BM (2015) Artemin immunotherapy is effective in preventing and reversing cystitis-induced bladder hyperalgesia via TRPA1 regulation. J Pain 16:628-636. CrossRef Medline

Engel MA, Leffler A, Niedermirtl F, Babes A, Zimmermann K, Filipović MR, Izydorczyk I, Eberhardt M, Kichko TI, Mueller-Tribbensee SM, Khalil M, Siklosi N, Nau C, Ivanović-Burmazovic I, Neuhuber WL, Becker C, Neurath MF, Reeh PW (2011) TRPA1 and substance P mediate colitis in mice. Gastroenterology 141:1346-1358. CrossRef Medline

Feng B, Gebhart GF (2011) Characterization of silent afferents in the pelvic and splanchnic innervations of the mouse colorectum. Am J Physiol Gastrointest Liver Physiol 300:G170-G180. CrossRef Medline

Feng B, Brumovsky PR, Gebhart GF (2010) Differential roles of stretchsensitive pelvic nerve afferents innervating mouse distal colon and rectum. Am J Physiol Gastrointest Liver Physiol 298:G402-G409. CrossRef Medline

Feng B, La JH, Schwartz ES, Gebhart GF (2012) Irritable bowel syndrome: methods, mechanisms, and pathophysiology: neural and neuro-immune mechanisms of visceral hypersensitivity in irritable bowel syndrome. Am J Physiol Gastrointest Liver Physiol 302:G1085-G1098. CrossRef Medline

Gershon MD (2013) 5-Hydroxytryptamine (serotonin) in the gastrointestinal tract. Curr Opin Endocrinol Diabetes Obes 20:14-21. CrossRef Medline

Giaroni C, Knight GE, Ruan HZ, Glass R, Bardini M, Lecchini S, Frigo G, Burnstock G (2002) P2 receptors in the murine gastrointestinal tract. Neuropharmacology 43:1313-1323. CrossRef Medline

Gunawardene AR, Corfe BM, Staton CA (2011) Classification and functions of enteroendocrine cells of the lower gastrointestinal tract. Int J Exp Pathol 92:219-231. CrossRef Medline

Heath JP (1996) Epithelial cell migration in the intestine. Cell Biol Int 20: 139-146. CrossRef Medline

Hicks GA, Coldwell JR, Schindler M, Ward PA, Jenkins D, Lynn PA, Humphrey PP, Blackshaw LA (2002) Excitation of rat colonic afferent fibres by 5-HT(3) receptors. J Physiol 544:861-869. CrossRef Medline

Hockley JR, Tranter MM, McGuire C, Boundouki G, Cibert-Goton V, Thaha MA, Blackshaw LA, Michael GJ, Baker MD, Knowles CH, Winchester WJ, Bulmer DC (2016) P2Y receptors sensitize mouse and human colonic nociceptors. J Neurosci 36:2364-2376. CrossRef Medline

King BF (2015) Purinergic signalling in the enteric nervous system: an overview of current perspectives. Auton Neurosci 191:141-147. CrossRef Medline

Liñán-Rico A, Wunderlich JE, Enneking JT, Tso DR, Grants I, Williams KC, Otey A, Michel K, Schemann M, Needleman B, Harzman A, Christofi FL (2015) Neuropharmacology of purinergic receptors in human submucous plexus: involvement of P2X(1), P2X(2), P2X(3) channels, P2Y and A(3) metabotropic receptors in neurotransmission. Neuropharmacology 95:83-99. CrossRef Medline

Linden DR, Chen JX, Gershon MD, Sharkey KA, Mawe GM (2003) Serotonin availability is increased in mucosa of guinea pigs with TNBS-induced colitis. Am J Physiol Gastrointest Liver Physiol 285:G207-G216. CrossRef Medline

Lynn PA, Blackshaw LA (1999) In vitro recordings of afferent fibres with receptive fields in the serosa, muscle and mucosa of rat colon. J Physiol 518:271-282. CrossRef Medline

Maksimovic S, Nakatani M, Baba Y, Nelson AM, Marshall KL, Wellnitz SA, Firozi P, Woo SH, Ranade S, Patapoutian A, Lumpkin EA (2014) Epidermal Merkel cells are mechanosensory cells that tune mammalian touch receptors. Nature 509:617-621. CrossRef Medline

Malin SA, Christianson JA, Bielefeldt K, Davis BM (2009) TPRV1 expression defines functionally distinct pelvic colon afferents. J Neurosci 29: 743-752. CrossRef Medline

Malin S, Molliver D, Christianson JA, Schwartz ES, Cornuet P, Albers KM, Davis BM (2011) TRPV1 and TRPAl function and modulation are target tissue dependent. J Neurosci 31:10516-10528. CrossRef Medline

Matsumoto K, Kurosawa E, Terui H, Hosoya T, Tashima K, Murayama T,
Priestley JV, Horie S (2009) Localization of TRPV1 and contractile effect of capsaicin in mouse large intestine: high abundance and sensitivity in rectum and distal colon. Am J Physiol Gastrointest Liver Physiol 297: G348-G360. CrossRef Medline

Matsumoto K, Lo MW, Hosoya T, Tashima K, Takayama H, Murayama T, Horie S (2012) Experimental colitis alters expression of 5-HT receptors and transient receptor potential vanilloid 1 leading to visceral hypersensitivity in mice. Lab Invest 92:769-782. CrossRef Medline

Mawe GM (2015) Colitis-induced neuroplasticity disrupts motility in the inflamed and post-inflamed colon. J Clin Invest 125:949-955. CrossRef Medline

Mawe GM, Hoffman JM (2013) Serotonin signalling in the gut: functions, dysfunctions and therapeutic targets. Nat Rev Gastroenterol Hepatol 10: 473-486. CrossRef Medline

Mueller-Tribbensee SM, Karna M, Khalil M, Neurath MF, Reeh PW, Engel MA (2015) Differential contribution of TRPA1, TRPV4 and TRPM8 to colonic nociception in mice. PLoS One 10:e0128242. CrossRef Medline

Pang Z, Sakamoto T, Tiwari V, Kim YS, Yang F, Dong X, Güler AD, Guan Y, Caterina MJ (2015) Selective keratinocyte stimulation is sufficient to evoke nociception in mice. Pain 156:656-665. CrossRef Medline

Patterson LM, Zheng H, Ward SM, Berthoud HR (2003) Vanilloid receptor (VR1) expression in vagal afferent neurons innervating the gastrointestinal tract. Cell Tissue Res 311:277-287. CrossRef Medline

Rindi G, Leiter AB, Kopin AS, Bordi C, Solcia E (2004) The "normal" endocrine cell of the gut: changing concepts and new evidences. Ann N Y Acad Sci 1014:1-12. CrossRef Medline

Robinson DR, McNaughton PA, Evans ML, Hicks GA (2004) Characterization of the primary spinal afferent innervation of the mouse colon using retrograde labelling. Neurogastroenterol Motil 16:113-124. CrossRef Medline

Sadler KE, McQuaid NA, Cox AC, Behun MN, Trouten AM, Kolber BJ (2017) Divergent functions of the left and right central amygdala in visceral nociception. Pain 158:747-759. CrossRef Medline

Sharrad DF, Hibberd TJ, Kyloh MA, Brookes SJ, Spencer NJ (2015) Quantitative immunohistochemical co-localization of TRPV1 and CGRP in varicose axons of the murine oesophagus, stomach and colorectum. Neurosci Lett 599:164-171. CrossRef Medline

Shinoda M, La JH, Bielefeldt K, Gebhart GF (2010) Altered purinergic signaling in colorectal dorsal root ganglion neurons contributes to colorectal hypersensitivity. J Neurophysiol 104:3113-3123. CrossRef Medline

Song X, Chen BN, Zagorodnyuk VP, Lynn PA, Blackshaw LA, Grundy D, Brunsden AM, Costa M, Brookes SJ (2009) Identification of medium/ high-threshold extrinsic mechanosensitive afferent nerves to the gastrointestinal tract. Gastroenterology 137:274-284.e271. CrossRef Medline

Spencer NJ, Kyloh M, Duffield M (2014) Identification of different types of spinal afferent nerve endings that encode noxious and innocuous stimuli in the large intestine using a novel anterograde tracing technique. PLoS One 9:e112466. CrossRef Medline

Sugiuar T, Bielefeldt K, Gebhart GF (2004) TRPV1 function in mouse colon sensory neurons is enhanced by metabotropic 5-hydroxytryptamine receptor activation. J Neurosci 24:9521-9530. CrossRef Medline

Taylor-Clark TE, McAlexander MA, Nassenstein C, Sheardown SA, Wilson S, Thornton J, Carr MJ, Undem BJ (2008) Relative contributions of TRPA1 and TRPV1 channels in the activation of vagal bronchopulmonary C-fibres by the endogenous autacoid 4-oxononenal. J Physiol 586:3447-3459. CrossRef Medline

Ueda T, Yamada T, Ugawa S, Ishida Y, Shimada S (2009) TRPV3, a thermosensitive channel is expressed in mouse distal colon epithelium. Biochem Biophys Res Commun 383:130-134. CrossRef Medline

Wang FB, Powley TL (2000) Topographic inventories of vagal afferents in gastrointestinal muscle. J Comp Neurol 421:302-324. CrossRef Medline

Wynn G, Rong W, Xiang Z, Burnstock G (2003) Purinergic mechanisms contribute to mechanosensory transduction in the rat colorectum. Gastroenterology 125:1398-1409. CrossRef Medline

Wynn G, Ma B, Ruan HZ, Burnstock G (2004) Purinergic component of mechanosensory transduction is increased in a rat model of colitis. Am J Physiol Gastrointest Liver Physiol 287:G647-G657. CrossRef Medline

Zagorodnyuk VP, Lynn P, Costa M, Brookes SJ (2005) Mechanisms of mechanotransduction by specialized low-threshold mechanoreceptors in the guinea pig rectum. Am J Physiol Gastrointest Liver Physiol 289:G397G406. CrossRef Medline 